\title{
Pembangunan Sistem Informasi Perpustakaan Digital Menggunakan Linear Sequential Model
}

\author{
Hidayanti Murtina ${ }^{1, *}$ \\ 1 Teknik Informatika; STMIK Nusa Mandiri Jakarta; Kampus Nusa Mandiri Tower Jatiwaringin, \\ Jln. Jatiwaringin Raya No. 02 RT.08/013 Kel. Cipinang Melayu Kec. Makasar, Jakarta Timur, \\ Telp : (021)28534236, 28534471, 28534390; e-mail: hidayantimurtina@gmail.com \\ *Korespondensi: e-mail: hidayantimurtina@gmail.com
}

Diterima: 23 Oktober 2020; Review: 29 Oktober 2020; Disetujui: 2 Oktober 2020;

Cara sitasi: Murtina.H. 2020. Pembangunan Sistem Informasi Perpustakaan Digital Menggunakan Linear Sequential Model. Informatics for Educators and Professionals. 5(1): 3342.

\begin{abstract}
Abstrak: Berdasarkan undang-undang pendidikan yang ada yang diatur pada undang-undang no 42 bab 1 pasal 1 . Keberadaan perpustakaan baik di sekolah ataupun lembaga pendidikan dan juga masyarakat itu sangat penting. Seperti istilah yang mengatakan bahwa buku adalah jendela dunia, maka keberadaan perpustakaan menjadi salah satu wadah ataupun tempat yang dapat membuat orang-orang bisa mengetahui hal-hal yang sebelumnya tidak mereka ketahui. Namun masih banyaknya perpustakaan konvensional yang ada dengan kondisi ditengah pandemic Covid-19 ini tentunya fungsi dari perpustakan menjadi menjadi berkurang, dikarenakan pemerintah menerapkan kebiasaan baru salah satunya dengan menjaga jarak dan menghindari kerumunan. Untuk itu penulis membangun sebuah sistem informasi perpustakaan digital menggunakan linear sequential model, sistem informasi perpustakaan digital ini di desain sedemikian rupa agar mengurangi terjadinya kontak fisik dan memudahkan mereka untuk tetap menggali ilmu pengetahuan tanpa harus tertular bahaya Covid-19.
\end{abstract}

Kata kunci: Linear Sequential Model, Perpustakaan Digital, Waterfall

\begin{abstract}
Based on the existing education law which is regulated in law no. 42 chapter 1 paragraph 1. The existence of libraries both in schools and educational institutions as well as the community is very important. As the term says that books are a window to the world, the existence of a library is a place or place where people can find out things they didn't know before. However, there are still many conventional libraries that exist in the midst of the Covid19 pandemic, of course the function of the library has become reduced, because the government is implementing new habits, one of which is by maintaining distance and avoiding crowds. For this reason, the authors built a digital library information system using a linear sequential model, this digital library information system is designed in such a way as to reduce the occurrence of physical contact and make it easier for them to continue to explore knowledge without having to contract the dangers of Covid-19.
\end{abstract}

Keywords: Linear Sequential Model, Digital Library, Waterfall

\section{Pendahuluan}

Membaca sangat diperlukan untuk menunjang pengetahuan yang harus dikuasai oleh peserta didik. Sehingga membaca tentunya menjadi kebiasaan yang harus dimiliki oleh seluruh peserta didik di Indonesia [1]. Menurut UU No. 42 Tahun 2007 pada Bab I pasal 1 menyatakan Perpustakaan adalah institusi pengelola koleksi karya tulis, karya cetak, dan/atau karya rekam secara profesional dengan sistem yang baku guna memenuhi kebutuhan pendidikan, penelitian, pelestarian, informasi dan rekreasi para pemustaka [2].

Berdasarkan undang-undang yang berlaku dapat terlihat betapa pentingnya keberadaan sebuah perpustakaan bagi pada peserta didik maupun masyarakat umum terlihat 
dari arti perpustakaan itu sendiri di undang-undang yaitu untuk memenuhi kebutuhan akan keingintahuan akan ilmu pengetahuan ataupun hanya sekedar sebagai sarana rekreasi bagi mereka yang memang gemar membaca.

Tujuan diselenggarakan Perpustakaan sekolah adalah untuk mengembangkan dan meningkatakan minat baca, literasi informasi, bakat dan kecerdasan (intelektual, emosional dan spiritual) peserta didik (siswa), pendidik (guru) dan tenaga kependidikan dalam rangka mendukung tujuan pendidikan nasional melalui penyediaan sumber belajar [3]. hal ini semakin memperkuat perlunya sebuah perpustakaan dan tentunya dengan kebutuhan yang ada saat ini kinerja dari pustakawan dituntut untuk semakin cepat dan lebih teliti lagi dalam mengelola dan juga melayani pengunjung perpustakaan.

Berada pada era 4.0 tentunya penerapan teknologi sudah tidak asing lagi bahkan menjadi kebutuhan dan konsumsi sehari-hari, teknologi memberikan manfaat kepada banyak golongan dan kepentingan mulai dari kepentingan bisnis, organisasi, pendidikan, pemerintahan sampai dengan hanya sebatas untuk media entertaiment saja seperti pernyataan berikut yang mengatakan Penerapan teknologi informasi saat ini telah menyebar hampir di semua bidang tidak terkecuali di perpustakaan [4] dan juga peran teknologi informasi dalam pendidikan, selain membantu siswa dalam belajar juga memiliki peran yang cukup berpengaruh bagi guru, terutama dalam penggunaan fasilitas [5].

Ada beberapa pendapat dari penelitian sebelumnya yang mengartikan perpustakaan antara lain mengungkapkan bahwa perpustakaan merupakan salah satu lembaga yang bergerak dibidang layanan jasa, baik layanan bersifat konvensional seperti peminjaman dan pengembalian, atau layanan yang bersifat modern (digital) [6]. Perpustakaan digital memberikan kemudahan bagi pengguna dalam memperoleh sumber informasi dengan mudah. Pengguna dapat dengan cepat mencari informasi data buku, mengetahui jumlah buku yang tersedia, melakukan peminjaman secara langsung dsb [7].

Melihat pembahasan tersebut tentunya peran pustakawan amatlah penting, mengingat perpustakaan adalah tempat kedua di sekolah bagi siswa/l mencari ilmu. Perpustakaan digital sendiri terutama di masa pandemic seperti yang terjadi saat ini menjadi semakin penting, dikarenakan adanya penerapan kebiasaan baru seperti menjaga jarak aman agar terhindar dari bahaya tertular Covid-19 yang tengah digadang-gadang oleh pemerintah. Namun masih banyak perpustakaan-perpustakaan sekolah yang masih menggunakan sistem konvensional dengan para siswa/l harus mendatangi secara langsung perpustakan dan mencari buku yang diminati secara langsung, bahkan tidak jarang mereka tidak dapat mengunjungi perpustakaan secara langsung dikarenakan adanya bahaya penularan Covid-19 seperti yang terjadi pada zona merah penularan Covid-19 maupun yang lainnya. Keadaan ini sejenak membuat fungsi perpustakaan menjadi lumpuh.

Untuk itu perlu adanya perubahan sistem perpustakaan konvensional yang ada saat ini menjadi sebuah perpustakaan digital yang lebih sistematis dengan memanfaatkan kecanggihan teknologi yang ada saat ini dengan memanfaatkan sebuh website perpustakaan atau yang dikenal dengan E-Library. Teknologi ini tidak hanya dapat bermanfaat pada masa pandemic saat ini saja tetapi disegala kondisi teknologi ini tentunya akan memberikan dampak positif baik bagi pihak sekolah terutama pengelola perpustakaan maupun bagi para siswa/i.

\section{Metode Penelitian}

Penulis menggunakan 2 metode dalam melakukan penelitian mengenai pembangunan perpustakaan digital ini yaitu metode pengumpulan data yang penulis gunakan antara lain observasi dan literature, sedangkan metode pengembangan perangkat lunak yang penulis gunakan adalah linear Sequential model.

Untuk metode pengumpulan data yang penulis lakukan pertama yang penulis lakukan adalah mengobservasi kegiatan yang dilakukan di perpustakaan konvensional mulai dari pendataan buku yang masih menggunakan buku besar, peletakan buku, pendaftaran anggota, proses peminjaman, proses pengembalian, pencatatan denda sampai dengan dilakukannya pelaporan.

Kegiatan kedua yang penulis lakukan adalah penulis melakukan kajian terhadap literature-literatur terkait yang berhubungan dengan perpustakaan maupun dengan penerapan teknologi informasi sehingga penulis semakin yakin bahwa perpustakaan digital saat ini sangatlah dibutuhkan keberadaannya terutama disaat seseorang tidak dapat mengunjungi perpustakaan secara langsung. 
Dan untuk model pengembangan perangkat lunak penulis menggunakan linear sequential model atau yang dikenal dengan classic life cycle yang disebut dengan metode waterfall.

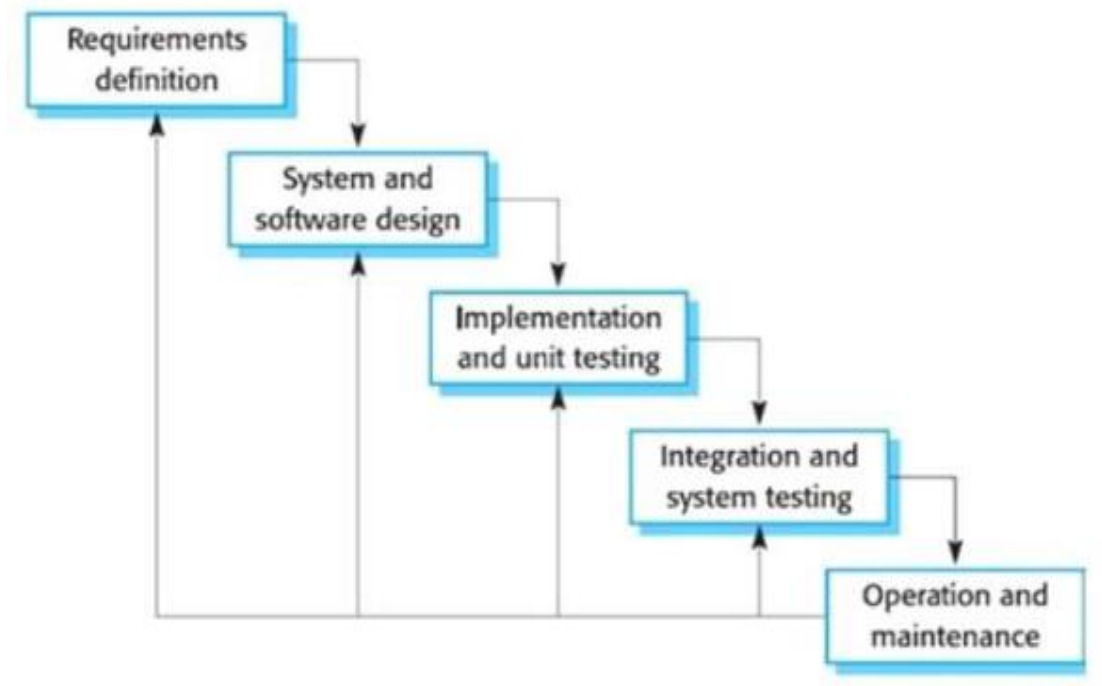

Sumber : Mukrodin \& Sugiamto (2020) [8]

\section{Gambar 1. Bagan Waterfall}

Pada tahapan requirements definition penulis mendefinisikan atau juga menganalisa dan merincikan apa-apa saja kebutuhan dari user dalam hal ini adalah user admin yaitu pustakawan dan juga user pengguna yaitu pengunjung perpustakaan didalam prosesnya yang berhubungan baik dengan pengelolahan data perpustakaan maupun dalam pemakaian ataupun peminjaman buku. Penulis juga mendefinisikan apa-apa saja yang menjadi kebutuhan sistem nantinya agar semua kebutuhan user dapat teratasi secara keseluruhan dengan baik.

Selanjutnya jika semua kebutuhan baik kebutuhan user maupun kebutuhan sistem dapat diketahu dengan pasti maka tahapan berikutnya adalah system and software design. Pada tahapan ini penulis menggunakan bantuan UML. "UML merupakan bahasa visual untuk pemodelan dan komunikasi mengenai sebuah sistem dengan menggunakan diagram dan teksteks pendukung .Beberapa pemodelan yang termasuk kedalam pemodelan UML seperti use case diagram, class diagram, activity diagram dan sequence diagram." [9]

Ditahapan ini penulis menggunakan Entity Relationship Diagram (ERD) didalam menggambarkan rancangan dari database yang digunakan. Untuk penggambaran kegiatan yang dapat dilakukan oleh user penulis menggunakan use case diagram, activity diagram penulis gunakan untuk merincikan secara detail tahapan yang dapat dilakukan oleh user sedangkan yang terakhir penulis menggunakan sequence diagram untuk menggambarkan proses yang dilakukan oleh sistem.

Tahap ketiga adalah Implementation and Unit Testing, tahapan ini adalah tahapan pengimplementasian dari design yang telah dibuat sebelumnya menjadi sebuah bentuk nyata berupa aplikasi baik berbentuk desktop, website maupun mobile yang diikuti dengan pengujian unit. "Pengujian adalah suatu proses pelaksanaan suatu program dengan tujuan menemukan suatu kesalahan." [10]

Setelah design diimplementasikan maka perlu dilakukan tahapan integration and system testing. Tahapan ini dilakukan jika program sudah siap untuk dipergunakan oleh user dengan menempatkan program di perangkat keras (hardware) yang digunakan oleh user serta melakukan kembali pengujian sistem untuk memastikan program yang sudah dibuat sebelumnya tetap dapat berjalan dengan baik dilapangan.

Dan tahapan terakhir adalah operating and maintenance, ditahapan ini sistem sudah sepenuhnya digunakan dan dikendalikan oleh user, pada tahapan ini juga user dapat melakukan evaluasi terhadap sistem dari program yang telah dihubungkan dengan perangkat keras (hardware) yang digunakan oleh user dan mempelajari lagi apakah ada kebutuhan dari user yang belum terpenuhi oleh sistem yang baru. 
Apabila masih terdapat kekurangan-kekurangan terhadap sistem maka perlu dilakukan maintenance terhadap sistem perpustakaan digital yang telah dibangun. Demikianlah tahapan dari pengumpulan data dan pengembangan perangkat lunak yang penulis lakukan dalam penelitian ini.

\section{Hasil dan Pembahasan}

Pada gambar 2 dapat terlihat sejauh ini perpustakaan konvensional masih banyak yang melakukan peminjaman buku secara fisik dan pengolahan data perpustakaan secara manual, itu artinya pustakawan harus benar-benar pintar dan cepat didalam mengelolah data buku dikarenakan kemungkinan terjadinya perbedaan antara fisik buku dan juga pencatatan. Biasanya perpustakaan konvensional melakukan pendataan buku dengan mencatatnya kedalam sebuah buku besar berdasarkan buku yang masuk sebagai acuan berapa banyak koleksi buku yang dimiliki perpustakaan.

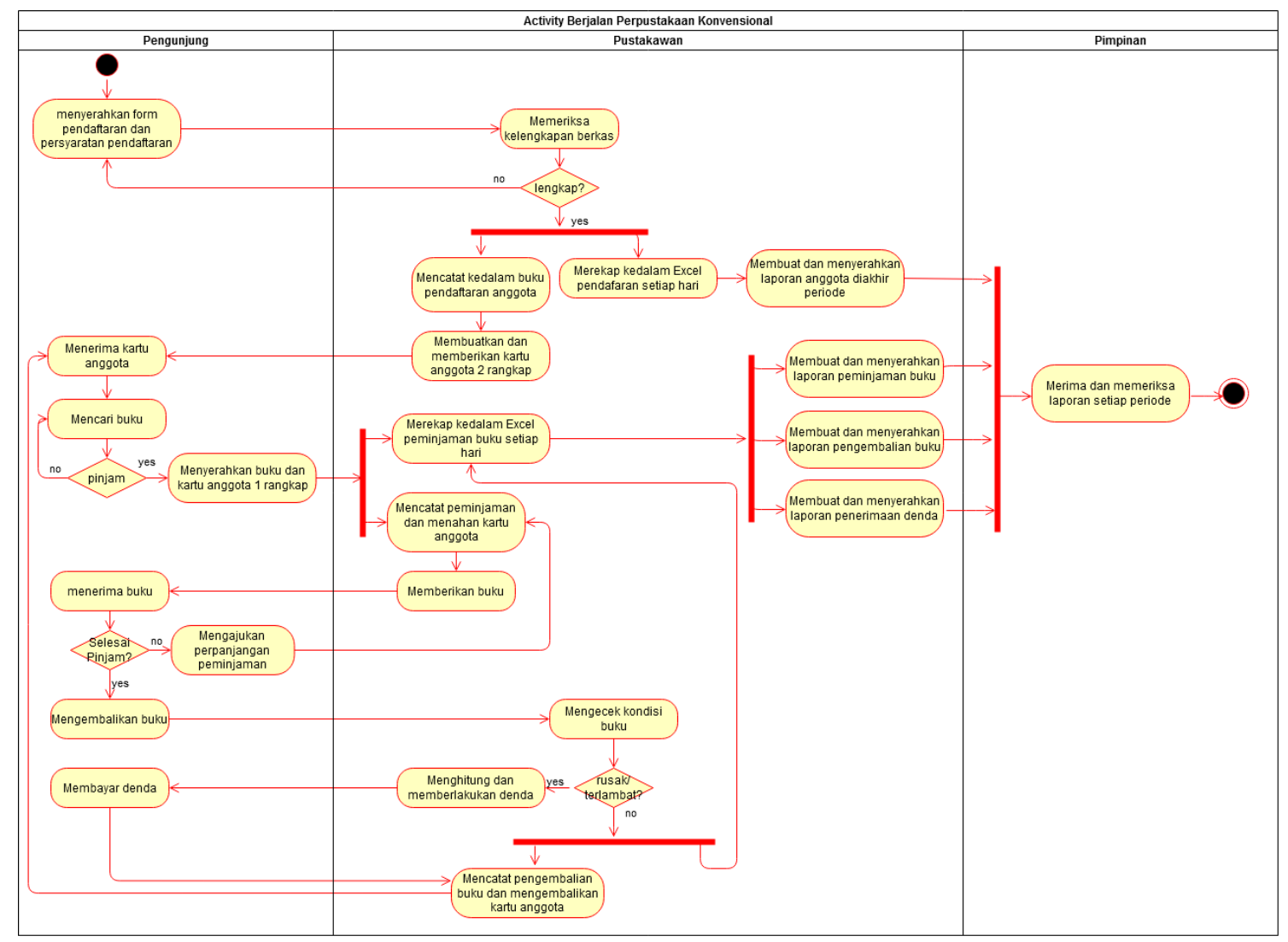

Sumber : Hasil Penelitian (2020)

Gambar 2. Activity Diagram Sistem Perpustakaan Konvensional

Kelemahan dari cara ini tentunya menyulitkan pustakawan untuk menandai buku mana saja yang masih benar-benar tersedia dan tidak lalu untuk pelaporannya pustakawan harus melihat dan meneliti lagi satu persatu mana saja koleksi yang masih disediakan dan mana saja yang tidak. Belum lagi kemungkinan jumlah buku yang berbeda dikarenakan peminjaman yang belum dikembalikan oleh pengunjung maupun dikarenakan buku rusak, sehingga proses pengecekan fisik buku dengan pencatatan akan memakan waktu lebih lama.

Perpustakaan konvensional juga melakukan pendataannya secara tertulis dan tidak jarang apabila pengunjung kehilangan kartu perpustakaan maka untuk meminjam buku pengunjung diharuskan mengurus kembali keanggotaan dan hal ini tentunya akan membuat duplikasi data dimana duplikasi data tersebut tentunya sangat tidak baik didalam melakukan pengelolahan data karna data yang tertulis dengan data real akan menjadi tidak valid.

Pada proses peminjaman perpustakaan konvensional juga hanya melakukan pencatatan pada buku besar transaksi peminjaman dan pengembalian. Hal ini membuat 
transaksi pengembalian menjadi lebih lama apalagi jika disaat yang bersamaan ada beberapa pengunjung yang ingin melakukan pengembalian dikarenakan harus mencari terlebih dahulu kapan dan siapa yang meminjam atau letak pencatatan peminjaman dari pengunjung tersebut. Belum lagi apabila disaat pengembalian pengunjung dikenakan denda karena keterlambatan, kerusakan maupun kehilangan tidak ada pencatatan yang pasti mengenai hal tersebut.

Pada periode berjalan tentunya pustakawan perlu melakukan pelaporan kepada pimpinan tertinggi sebagai bentuk pertanggungjawaban akan amanah yang dipegangnya, hal ini tentunya bukanlah hal yang mudah karena banyaknya data yang harus ditelaah dan disusun ulang dalam bentuk laporan.

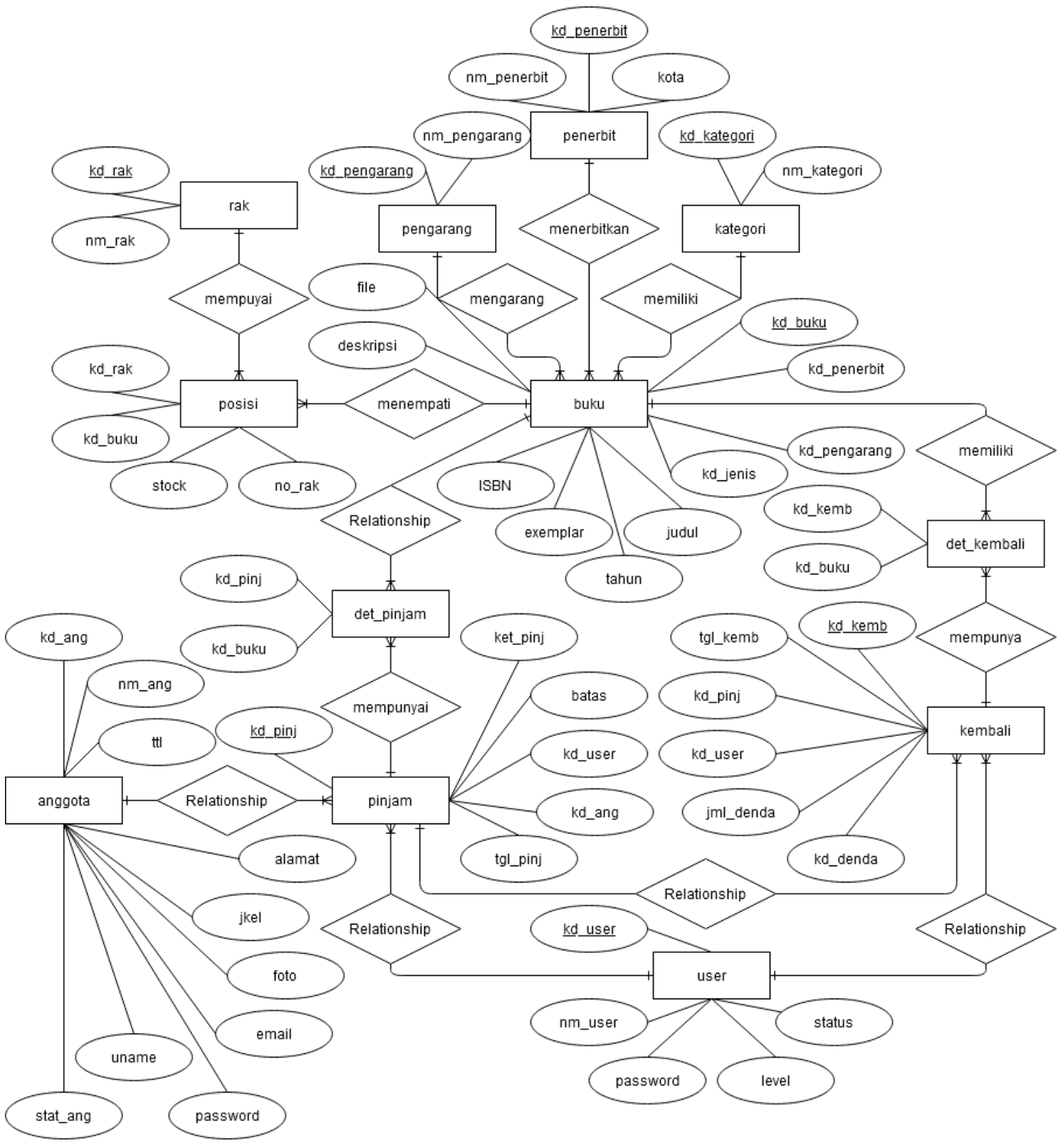

Sumber : Hasil Penelitian (2020)

Gambar 3. Entity Relationship Diagram (ERD) Sistem Informasi Perpustakaan Digital

Pada tahapan pengembangan perangkat lunak berdasarkan hasil analisis penulis terhadap sistem konvensional yang ada dan analisa kebutuhan yang penulis lakukan maka didapatlah rancangan database dalam bentuk Entity Relationship Diagram (ERD) untuk menampung semua data yang diperlukan dan dapat diintegrasikan antara satu dengan yang 
lain. Berikut adalah rancangan Entity Relationship Diagram (ERD) yang penulis rancang untuk memenuhi kebutuhan penyimpanan dan pemakaian data pada pada perpustakaan konvensional yang terlihat pada gambar 3 .

Setelah rancangan dari database berupa Entity Relationship Diagram (ERD) dibuat selanjutnya adalah mendeskripsikan dengan jelas akses atau kegiatan yang dapat dilakukan oleh setiap user terhadap sistem dengan menggunakan bantuan Use Case Diagram. Seperti yang terlihat pada gambar 4 .

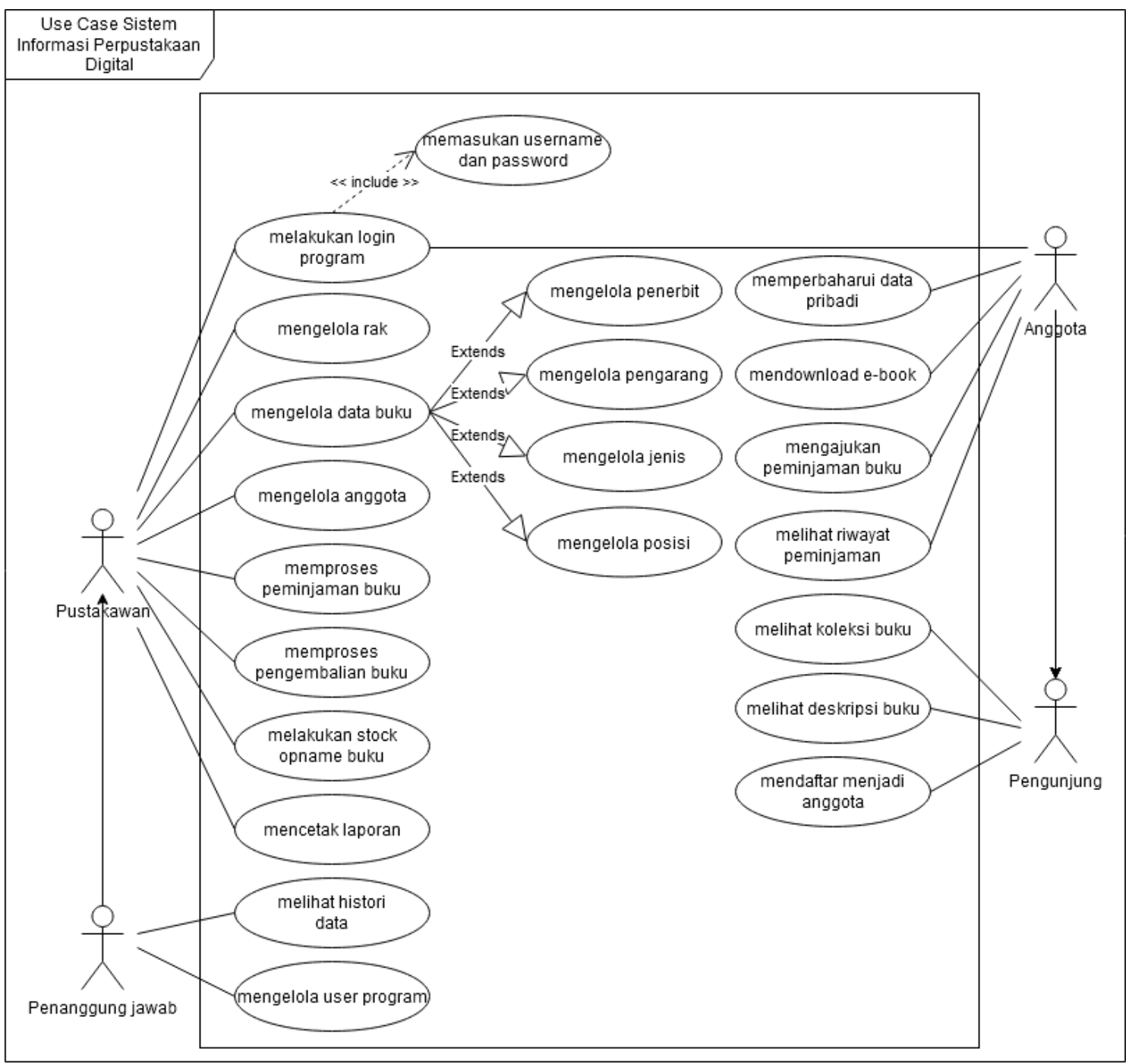

Sumber : Hasil Penelitian (2020)

Gambar 4. Use Case Diagram Sistem Informasi Perpustakaan Digital

Dari gambar 4 dapat terlihat jelas apa-apa saja yang dapat dilakukan user dalam menggunakan sistem informasi perpustakaan digital. Disini penulis merepresentasikan antara sistem yang dilakukan perpustakaan konvensional dengan sistem yang dapat dilakukan oelh perpustakaan digital.

Secara garis besar apa yang dilakukan oleh perpustakaan digital hampir sama dengan perpustakaan konvensional, akan tetapi dengan menggunakan sistem informasi perpustakaan digital akan lebih mempermudah pustakawan dalam melakukan pengelolahan data yang ada di perpustakaan, dengan membiarkan sistem menjalankan tugasnya secara sistematis. Selain itu perpustakaan digital juga menyediakan fasilitas yang dapat digunakan oleh pustakawan untuk dapat mendata secara jelas apabila ditemui adanya buku yang rusak ataupun yang hilang dengan mengisi atau menggunakan fasilitas stock opname buku. Untuk data buku dan transaksi 
peminjaman serta pengembalian juga sudah saling terintegrasi sehingga pustakawan tidak perlu lagi melakukan pencarian secara manual.

Dan yang membedakan antara sistem perpustakaan konvensional dengan perpustakaan digital untuk pustakawan adalah saat melakukan pelaporan atau membutuhkan untuk mencetak laporan, pustakawan tinggal menggunakan fasilitas cetak laporan tanpa harus menyusun laporan dari awal karna semua data sudah daling terhubung.

Tidak hanya kemudahan yang ditawarkan kepada pustakawan saja, akan tetapi pemegang tanggung jawab dan anggota ataupun pengunjung juga akan lebih diberikan kemudahan didalam memanfaatkan fasilitas perpustakaan. Sebagai pemegang tanggung jawab tentunya harus mengetahui secara detail pergerakan data yang ada di perpustakaan, apakah ada yang mencurigakan ataukah tidak. Dengan sistem informasi perpustakaan digital maka pemegang tanggung jawab dapat melacak alir data yang ada. Selain itu juga dapat melihat laporan mengenai data-data perpustakaan kapanpun dibutuhkan tanpa harus menunggu pustakawan membuatkan dan menyerahkan laporan.

Bagi anggota adanya sistem informasi perpustakaan digital tentunya juga bisa lebih mempermudah anggota dalam melakukan pencarian buku yang diinginkan, selain itu juga perpustakaan digital juga menyediakan fasilitas e-book yang dapat dimanfaatkan agar para anggota dapat membaca buku referansi tanpa harus dating langsung ke perpustakaan untuk mengambil buku yang diinginkan. Bagi buku yang tidak memiliki softcopy berupa e-book maka anggota dapat melakukan pengajuan pinjaman buku apabila buku di perpustakaan tersedia, sehingga anggota dapat lasngung mengambil buku yang diinginkan saat mendatangi perpustakaan sehingga dapat meminimalisir terjadinya interaksi yang berlebihan selama berada di perpustakaan.

Bagi pengunjung yang belum menjadi anggota juga diberikan fasilitas untuk dapat mendaftar menjadi anggota perpustakaan tanpa harus mendatangi perpustakaan secara langsung. Pengunjung juga dapat melihat dan mencari koleksi di perpustakaan untuk memastikan apakah buku yang pengunjung cari tersedia di perpustakaan.

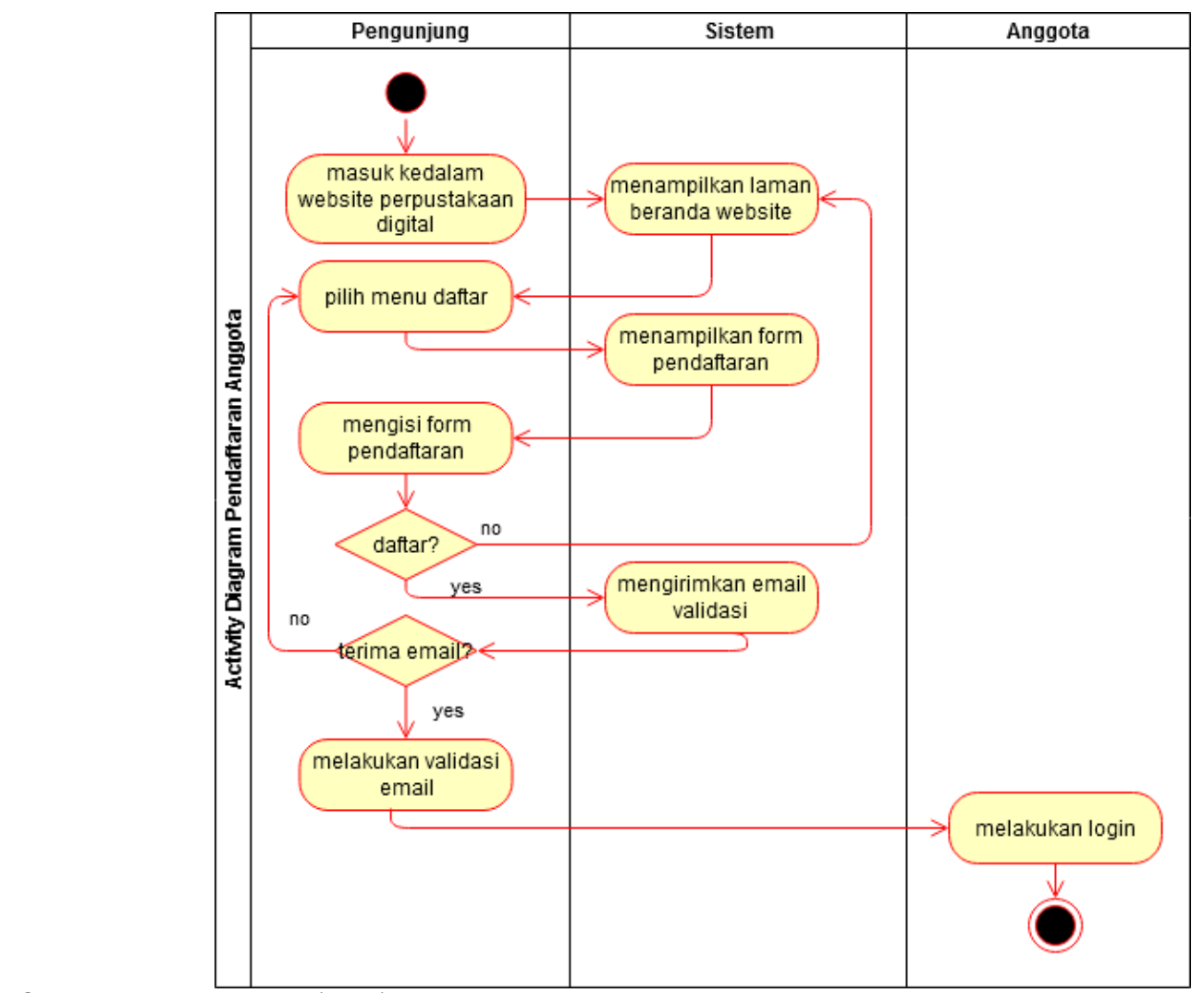

Sumber : Hasil Penelitian (2020)

Gambar 5. Activity Diagram Pendaftaran Anggota

Pada gambar 5 dapat terlihat jelas bahwa untuk melakukan pendaftaran sebagai anggota dengan menggunakan sistem informasi perpustakaan digital maka proses pendaftaran 
dapat dilakukan dengan lebih mudah bila dibandingkan dengan melakukan pendaftaran secara langsung. Dengan begitu maka beban kerja pustakawan untuk melakukan proses pencatatan pendaftaran secara otomatis akan tergantikan oleh sistem yang baru.

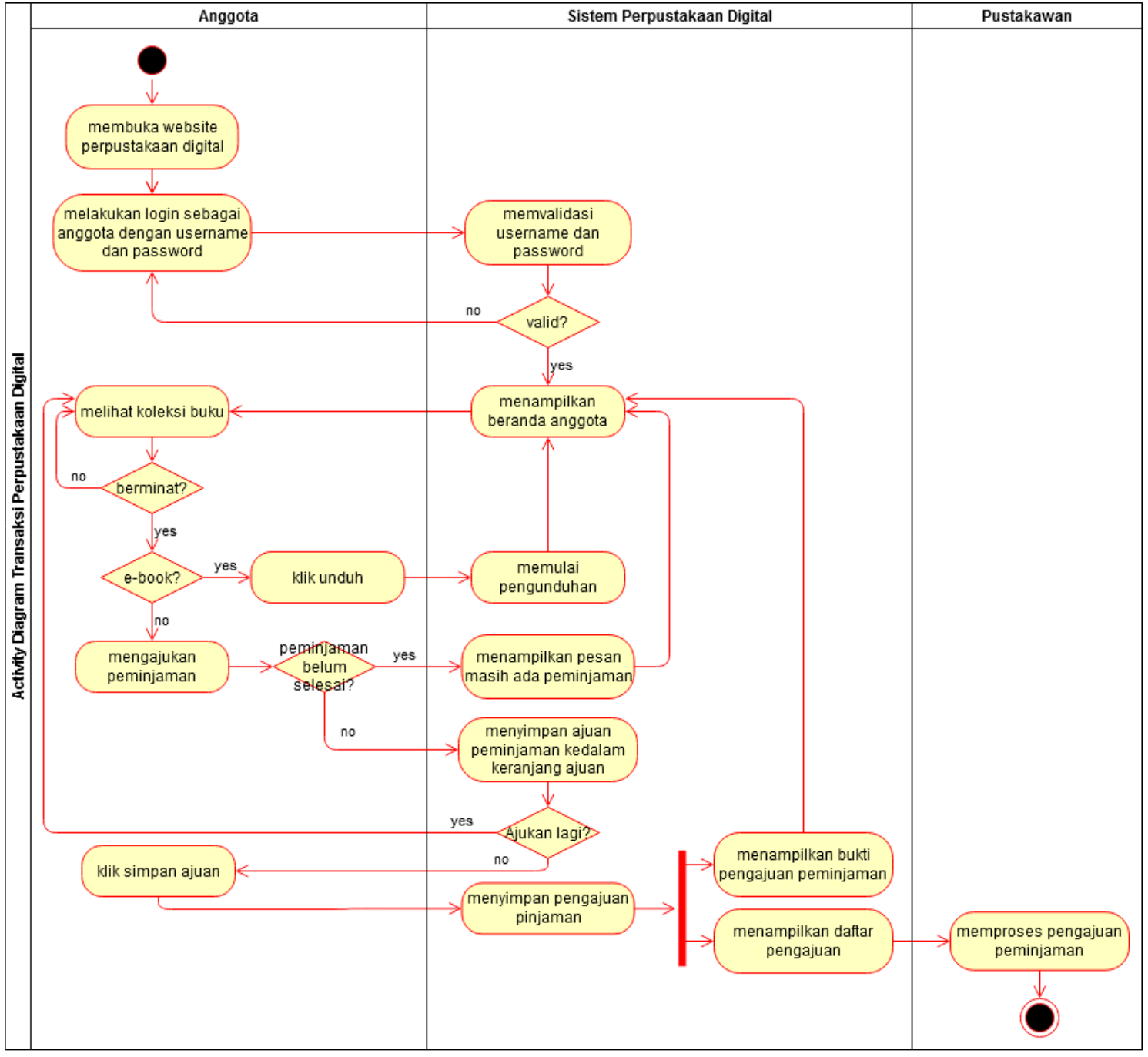

Sumber : Hasil Penelitian (2020)

Gambar 6. Activity Diagram Transaksi Perpustakaan Digital

Pada gambar 6 dapat terlihat aktifitas dari sistem informasi perpustakaan digital yang penulis gambarkan dengan activity diagram, pada gambar ini dapat terlihat perbedaan antara sistem perpustakaan konvensional dengan sistem perpustakaan digital. Dimana dengan menggunakan sistem informasi perpustakaan digital tentunya akan lebih mempermudah pustakawan dalam melakukan pengelolahan data peminjaman, sedangkan bagi anggota akan dipermudah dengan adanya fasilitas e-book karena anggota tidak perlu repot datang ke perpustakaan untuk mengambil buku yang ingin dipinjam.

Akan tetapi dengan sistem informasi perpustakaan digital ini juga tidak menutup kemungkinan bagi anggota yang lebih senang membaca buku secara fisik untuk melakukan peminjaman dengan melakukan pengajuan peminjaman terlebih dahulu, dengan seperti itu maka anggota tidak perlu menghabiskan waktu di perpustakaan untuk mencari buku, takut kehabisan buku yang akan dipinjam saat sudah datang ke perpustakaan dan juga tentunya mengurangi kontak fisik yang ada jika semua masih dilakukan secara konvensional. 


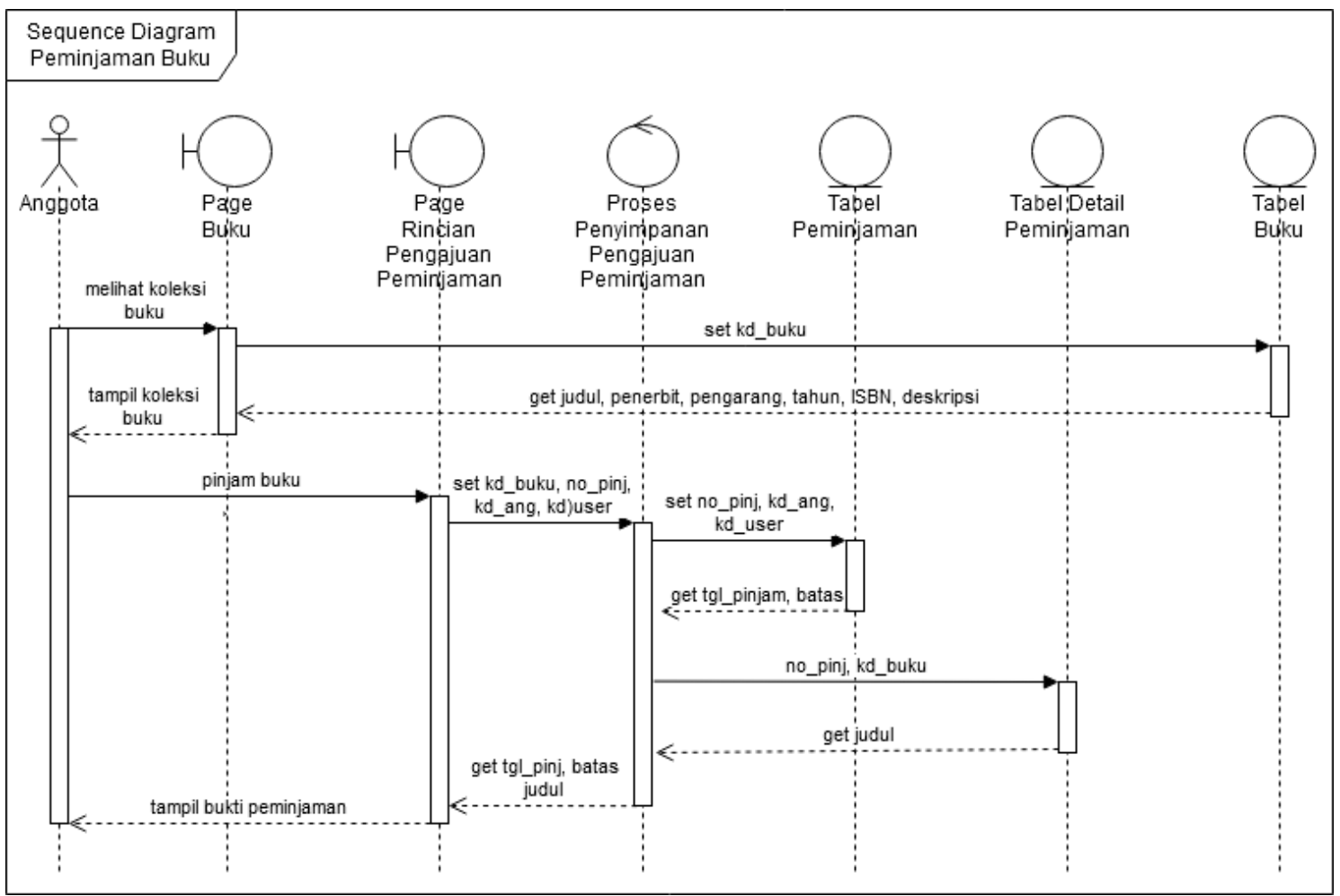

Sumber : Hasil Penelitian (2020)

Gambar 7. Sequence Diagram Transaksi Peminjaman Sistem Informasi Perpustakaan Digital

Pada gambar 7 dapat terlihat alur data sistem yang terjadi pada saat melakukan transaksi peminjaman. Dapat terlihat dengan jelas bahwa antara data yang satu dengan yang lain saling terhubng atau terintegrasi dengan baik, sehingga jika menerapkan penggunaan teknologi khususnya pada bagian sistem informasi maka didalam penyimpanan tentunya akan lebih menghemat ruang penyimpanan serta akan lebih mudah didalam pengelolahan datanya.

\section{Kesimpulan}

Dengan memanfaatkan kecanggihan teknologi dan juga menerapkan sistem informasi yang baik tentunya akan memberikan dampak baik yang sangat signifikan, karena jika adanya teknologi yang canggih tetapi sistem yang dijalannya tidak baik maka informasi yang dihasilkan tentu akan tidak baik. Sebaliknya jika sistem yang dijalankan sudah baik tetapi belum atau tidak memanfaatkan teknologi yang ada tentu penyajian informasikan akan menjadi tidak efektif atau bahkan bias menjadi tidak relevan. Untuk itu didalah pengelolahan data diperlukan adanya penggabungan teknologi dan juga sistem informasi yang baik agar kualitas dari informasi yang dihasilkan menjadi lebih relevan, efektif dan efisien.

Dengan menerapkan perpustakaan digital, maka tidak hanya pengelolahan datanya saja yang menjadi baik tetapi juga penyampaian informasi kepada yang membutuhkan juga akan menjadi semakin cepat. Tingkat efisiensi yang dicapai juga semakin tinggi karena adanya penghematan biaya, waktu, ruang penyimpanan dan sebagainya. Perpustakaan digital juga mampu memberikan kesempatan bagi mereka yang tidak dapat mengunjungi perpustakaan untuk tetap belajar dengan memanfaatkan fasilitas yang disediakan.

Peneliti menyadari masih banyak sekali kekurangan didalam penelitian ini yaitu diperlukannya sebuah bentuk nyata dari rancangan penelitian yang telah penulis bangun kedalam sebuah website perpustakaan digital.

\section{Referensi}

[1] I. Syarif and E. Elihami, "Pengadaan Taman Baca Dan Perpustakaan Keliling Sebagai Solusi Cerdas Dalam Meningkatkan Minat Baca Peserta Didik SDN 30 Parombean Kecamatan Curio," vol. 1, pp. 109-117, 2020.

[2] U.-U. R. Indonesia, "Undang-Undang Republik Indonesia Nomor 43 Tahun 2007 
Tentang Perpustakaan," Republik Indonesia, 2007. https://www.perpusnas.go.id/lawdetail.php?lang=id\&id=170920114322Ir9g6HhRuc.

[3] A. Suharto and M. Majid, "Sistem Informasi Perpustakaan Berbasis Rfid Dengan Metode Rapid Application Development ( Studi Kasus Smk Iptek Tangsel )," J. IImu Komput., vol. III, no. 03, pp. 35-41, 2020.

[4] R. D. Oktaviani and I. Seprina, "Rancang bangun sistem informasi perpustakaan sma pusri palembang menggunakan barcode," in Bina Darma Conference on Computer Science 2020, 2020, pp. 89-96.

[5] H. Budiman, "Peran Teknologi Informasi Dan Komunikasi Dalam Pendidikan," J. Pendidik. Islam, vol. 8, no. I, pp. 31-43, 2017.

[6] M. F. Wicaksono and F. Rizka, "Penerapan Konsep Visitor Experience Dalam Upaya Mewujudkan Perpustakaan Digital di Era Society 5.0," BIBLIOTIKA J. Kaji. Perpust. dan Inf., vol. 3, no. 2, pp. 114-122, 2019.

[7] H. M. Jumasa, "Rancang Bangun Digital Library Berbasis Mobile (Studi Kasus: Universitas Muhammadiyah Purworejo)," INTEK J. Inform. dan Teknol. Inf., vol. 2, no. 1, pp. 32-38, 2019, doi: 10.37729/intek.v2i1.87.

[8] Mukrodin and Sugiamto, "Implementasi Metode Waterfall Dalam Membangun Tracer Study Dan Penerimaan Peserta Didik Baru Dengan Pengujian Black Box Testing," J. Din., vol. 25, no. 1, pp. 39-50, 2020.

[9] R. A. Sukamto and M. Shalahuddin, Kolaborasi Rekayasa Perangkat Lunak Terstruktur dan Berorientasi Objek. Bandung: Informatika, 2015.

[10] M. S. Mustaqbal, R. F. Firdaus, and H. Rahmadi, "Pengujian Aplikasi Menggunakan Black Box Testing Boundary Value Analysis,” J. IIm. Teknol. Inf. Terap., vol. I, no. 3, pp. 31-36, 2015. 